\title{
Planning Indicators for Developing the Role of Team Work in the use of Social Support with Battered Women
}

Sanaa M ohammad Zahran 0 mar (PhD)

Assistant Professor at Social planning Department Faculty of Social Work, Assiut University, Egypt 

Planning Indicators for Developing the Role of Team Work in the use of Social Support with Battered Women

\section{Sanaa Mohammad Zahran Omar (PhD)}

Assistant Professor at Social planning Department

Faculty of Social Work, Assiut University, Egypt

\section{Abstract}

This study aims at developing the role of teamwork in supporting battered women by determining the degree of social support that women receive, the effective performance indicators of the work team, and the activities related to the actual roles of the social worker in the support centers for women. The difficulties that limit the effectiveness and complementarity of the teamwork role in the women support centers, and the proposals provided to confront them are determined. This study is based on the comprehensive social survey of the work team within the women support centers in Cairo, Alexandria, Gharbia, Qalawia, Dakahlia, Beni Suef, Aswan and Assiut.

The study group includes (24) specialists. A questionnaire prepared and conducted by the researcher, to determine a set of planning indicators to help develop the role of the work team in the use of social support with battered women.

Keywords: Team Work, Battered Women, Social work.

\section{Introduction}

Since the emergence of the social work profession in different societies, it seeks to achieve its objectives to contribute to satisfying the needs and solving problems in various fields. After proving its success in different areas, especially schools, hospitals and social institutions, it began to seek to add new areas. (Kassem, 2004, p. 3719). Social work is one of the professions that helps society in facing its problems, developing its capabilities, and helps social systems in playing their roles as well as finding new systems that show the urgent need for them. Social workers and other specialists work together to address social problems and help people improve their abilities and manage their daily lives. This collaboration between the social worker and other disciplines is a common trend in modern society, so-called teamwork (El Gohary \& Abd El Mohsen, 1991, p28). 
Teamwork is an entire organizational philosophy, A different way of thinking, and a winning path that companies have discovered in recent years to make the worker really truly commit to the objectives and to achieve high efficiency and quality in producing or providing a good or service. The aspects that conduct teamwork are (Allen, 1975):

* Self-knowledge and self-control.

* Shared Vision.

* Sharing mental models.

* Learning through dialogue.

The teamwork is a necessity for the success and progress of organizations, in the light of the requirements of achieving a higher level of quality. Work teams are an effective tool for accomplishing common tasks. Work experience has shown that any group of people can become a force that shares goals and tasks and collaborates to achieve the desired success (Abu El-Nasr, 2004, pp. 19-20).

Tomas (2002) presented a study to examine the impact of the implementation of the new law on the 1994 law on family protection and intervention to eliminate violence and family disputes. The results of the study examined the basic hypotheses underlying this study:

(i) The results in cases of violence within the Family Court will not change despite the existence of severe penalties in the new law.

(ii) The mediation is conducted in the light of the culture of the Family Court through the Family Court Working Group. Lawyers, judges and social workers work together to achieve the goal of the Family Court accurately and effectively resolve the cases.

(iii)The desire to settle differences of opinion has only been strongly felt after the promulgation of the law.

(iv)The teamwork has different political ideas and approaches to the issues involved and deals with them but has no impact on the outcome of the case.

The study of Salem (2005) aimed to define and improve the image of the social worker's performance in the professional practice at the offices of the family settlement disputes and courts through the professional rehabilitation of social workers. The study aimed at helping them acquire the skills and modern methods that help them to carry out the current professional role in a way that achieves the philosophy of establishing offices. The settlement of family disputes and family courts, and the provision of an appropriate perception to address occupational and administrative problems involving the social worker, as well as the team work working with family dispute settlement offices and the family court. 
Also were addressed Dandrawi( 2003), Mustafa( 2005), Selim, (2006) and Sandra( 1991) declared that. ** The importance of dealing with social worker with other disciplines, the availability of elements that increase the effectiveness of teamwork and the spirit of teamwork leads to fruitful cooperation, to treat family problems well.This is what the present study is looking for especially since it is noticeable that there is a paucity in the studies of the collective work in the field of women in general and the violence against them and how they support them to face the pressures of life in particular. This may be due to the recent experience of women support centers in Egypt.

The Social Science Glossary defines the team as "the spirit that results from the cooperation of a group of individuals to achieve a common goal" (Badawi, 1986, p. 422).Deborah (1994) defines the team as "a small group of people with integrated skills and a shared goal that we are committed to".Teamwork is the best framework for interpersonal interaction and communication. Positive teamwork can be a major source of achievement and integration among professions engaged in satisfying needs and facing problems (Neil, 2000, P 179).

The team consists of professionals in different disciplines, where they meet to discuss special cases of customers who deal with them each in the field of specialization in an integrated manner (Sulaiman, 2005, p. 129). Team members contribute their own talents and use continuous communication processes, Reexamination, and Evaluation. Its common objective is to take responsibility for the consequences of their actions" (Niazi, 2000, p. 157). The team can be defined as "a number of specialized individuals each with knowledge and skill, collaborating as professionals with each other to achieve a specific goal (Sayed, 1993, p.36). Given this concept, it becomes clear that it is not enough for a team member to have the knowledge but most importantly to have the skill to use and apply Knowledge in the team" (Ali, 2002, p. 397).

The Webster Dictionary defines the concept of the team as a group of specialists, each of whom performs its role accurately to perform the work effectively, and to achieve a common goal (Webster's, 1964, p.495).The working team is a method of work and management based on the importance of cooperation and coordination among the group of professionals with different specialties, in the completion of the work required of them more efficiently and effectively (Abu El-Nasr, 2009, p46). 
The concept of the team Work in the context of social work practice in the Women's Support Centers can be defined as "cooperation between the social worker, the psychologist and the legal specialist within the Center in order to achieve the objectives of the Center in dealing with abused women or girls, each working according to its specialization and benefiting from the expertise and skills of each member of the team to achieve integration and coordination in a moral and ethical framework based on confidentiality and respect". Violence against women is a broader term than domestic violence because it encompasses forms of violence perpetrated against women that do not occur in a 'domestic' setting, such as non-partner sexual assault, or violence and harassment experienced in a public place. The term "violence against women" means any act of gender-based violence that results in, or is likely to result in, physical, sexual or psychological harm or suffering to women, including threats of such acts, coercion or arbitrary deprivation of liberty, whether occurring in public or private life. (United Nations, 1993) Accordingly, violence against women encompasses but is not limited to the following: (Our Watch, 2015)

a) Physical, sexual and psychological violence occurring in the family, including battering, sexual abuse of female children in the household, dowry-related violence, marital rape, female genital mutilation and other traditional practices harmful to women, non-spousal violence and violence related to exploitation;

b) Physical, sexual and psychological violence occurring within the general community, including rape, sexual abuse, sexual harassment and intimidation at work, in educational institutions and elsewhere, trafficking in women and forced prostitution;

c) Physical, sexual and psychological violence perpetrated or condoned by the State, wherever it occurs.

Acts of violence against women also include forced sterilization and forced abortion, coercive/forced use of contraceptives, female infanticide and prenatal sex selection (United Nations, 1993).Twenty years ago, violence against women was not considered an issue worthy of international attention or concern. Victims of violence suffered in silence, with little public recognition of their plight. This began to change in the 1980s as women's groups organized locally and internationally to demand attention to the physical, psychological, and economic abuse of women. 
Gradually, violence against women has come to be recognized as a legitimate human rights issue and as a significant threat to women's health and well-being (Ellsberg \& Heise, 2005).Violence against women is a serious violation of human rights. This violence is mainly directed at women and girls. Its impact extends from immediate impact to long-term impact on the physical, sexual and psychological aspects, and negatively affects the well-being of women in general and prevents their full and effective participation in society (WHO, 2016).

The Egyptian government launched a unit to follow up the crimes of violence against women in May 2013, as well as the establishment of departments to combat violence against women in the security departments and the launching of the national strategy to combat violence against women prepared by the National Council for Women. It was published on 7 May 2015, (2015-2020), which aims to coordinate many bodies, including a number of ministries, national councils and bodies of a special nature, to work together to raise awareness of the crimes of violence against women and to provide support to survivors (Ahmed, 2015, pp. 4-5).In order to address the phenomenon of violence and reduce its negative effects, the society must join hands and cooperate with the affected groups, provide them with the assistance and social support they need, and thus show the importance of social support to stand by the injured person, and not be alone in the face of difficulties.

This support would give the individual a moral boost towards hope and optimism. Women as emotional beings are among the most vulnerable groups in need of support to combat stressful life conditions (http://i.cdn.turner.com).In this context, the idea of support centers for women that deal with violence against women was formed. The teamwork of these centers is composed of a number of social, psychological and legal experts to provide counseling, social, psychological and legal support to the victim as well as awareness of risks, safety and safety plans. The need is all within a moral and ethical framework built on confidentiality, safety, mutual respect and exchange of views and experiences with excellence in the work of providing high quality services. Therefore, the idea of supporting women's centers is based on the empowerment and social support of women, through the joint efforts of the teamwork members. It raises many questions about the foundations and structural characteristics of this team and the use of social support and other issues of team work which is the focus of the current study. 
Objectives of the study: The main objective of this study is "to define the planning indicators that help develop the role of the Team work in support centers for women in dealing with battered women."

The main question of this study is: What are the planning indicators that enable the teamwork to support women and to deal effectively with abused women?

The following sub- questions were developed from the main study question:

1.What are the effective performance indicators of the Teamwork on Women Support Centers?

2.What activities are carried out by the social worker within the teamwork of women's support centers?

3. What are the difficulties that limit the effectiveness and complementarity of the roles of the teamwork in the support centers for women?

4.Can indicators be drawn from the above data to activate the roles of the teamwork in support centers women?

\section{Methodology:}

- This study is considered as a descriptive study, which relied on the social survey of the work team within women's support centers.

\section{- Research limits or Fields}

Place Limit: This study was applied at the women's support centers in Cairo, Alexandria, Gharbia, Qalawia, Dakahlia, Beni Suef, Aswan and Assiut.

Human limit: All the members of the teamwork, which includes social workers, psychologists and jurists who work in women's support centers, the total of their number are 24.

Time limit: the study data were collected from April 2019 to June 2019.

- Data collection tools: The researcher used in this study: -

A questionnaire prepared by the researcher.

\section{Validity and reliability for the Study Questionnaire:}

To ensure the validity of the study tool, it was judged by an academic staff from the Faculty of Social Work - Helwan University and Assiut University to define the appropriateness of the tool in regarding its language and its relevance to the study variables. According to that, some statements were modified, some were added, and some were removed. 
To achieve the reliability of the study tool the test- retest method was applied, by applying the tool upon (10 specialists) then after 15 days the tool was applied again on the same subjects (specialists), then the relation between the two tests was found using the alpha-Cronbach coefficient, and the results were as following :

Table (1) The Reliability of the study tool by using alphaCronbach coefficient

\begin{tabular}{|l|l|l|}
\hline M & \multicolumn{1}{|c|}{ Tool's variables } & \multicolumn{1}{|c|}{$\begin{array}{c}\text { The value of alpha-Cronbach } \\
\text { coefficient }\end{array}$} \\
\hline 1 & $\begin{array}{l}\text { characteristics to be met in the team } \\
\text { work }\end{array}$ & 0.768 \\
\hline 2 & the structural foundations available & 0.795 \\
\hline 3 & positions that require cooperation & 0.834 \\
\hline 4 & tools and methods used by the team & 0.772 \\
\hline 5 & indicators of the effective performance & 0.837 \\
\hline 6 & $\begin{array}{l}\text { activities performed by the social } \\
\text { worker }\end{array}$ & 0.863 \\
\hline Total & 0.806 \\
\hline
\end{tabular}

According to the previous table, results indicate that the study tool is valid and adequate for applying. The questionnaire was prepared in its final form to collect the target data in this study.

\section{Results of field study}

\section{Field tables:-}

Table (2) shows the description of the study sample (team) $\mathbf{n}=\mathbf{2 4}$

\begin{tabular}{|c|c|c|c|c|}
\hline No & \multicolumn{2}{|c|}{ Qualitative variables } & Frequency & $\%$ \\
\hline \multirow{2}{*}{1} & \multirow{2}{*}{ Gender } & Male & 8 & 33.33 \\
\hline & & Female & 16 & 66.67 \\
\hline \multirow{3}{*}{2} & \multirow{3}{*}{ Age } & $25-35$ years & 5 & 20.83 \\
\hline & & $35-45$ years & 13 & 54.17 \\
\hline & & $45+$ years & 6 & 25 \\
\hline \multirow{2}{*}{3} & \multirow{2}{*}{ Social status } & Single & 5 & 20.83 \\
\hline & & Married & 19 & 79.17 \\
\hline \multirow{3}{*}{4} & \multirow{3}{*}{ Current job } & Social worker & 8 & 33.33 \\
\hline & & Psychologist & 8 & 33.33 \\
\hline & & Legal specialist & 8 & 33.33 \\
\hline \multirow{3}{*}{5} & \multirow{3}{*}{$\begin{array}{c}\text { Years of } \\
\text { professional } \\
\text { experience }\end{array}$} & Less than one year & 2 & 8.33 \\
\hline & & one - Three years & 12 & 50 \\
\hline & & Three years and more & 10 & 41.67 \\
\hline \multirow{3}{*}{6} & \multirow{3}{*}{ Duration of work } & Less than one year & 2 & 8.33 \\
\hline & & one - Three years & 19 & 79.17 \\
\hline & & Three years and more & 3 & 12.5 \\
\hline \multirow{2}{*}{7} & \multirow{2}{*}{$\begin{array}{l}\text { Number of training } \\
\text { courses }\end{array}$} & Two courses & 5 & 20.83 \\
\hline & & More & 19 & 79.17 \\
\hline \multicolumn{2}{|c|}{ Total } & & Percentage & $100 \%$ \\
\hline
\end{tabular}


As shown in the above table: the highest percentage of the teamwork in the study was female $(66.67 \%)$, while the male percentage was $(33.33 \%)$. This is because female socialists and female psychologists are among the conditions for the formation of the teamwork of women's support centers. The largest proportion of workers in women's support centers between the ages of 35 and 45 years and this age group is characterized by the ability to balance the emotional and the ability to assess positions.

The highest percentage of the teamwork in the study was married $(79.17 \%)$. This may help the members of the team feel the importance of the role of women as well as the wife and daughter and the problems that may be faced and try to reach solutions to these problems. The highest percentage among the members of the teamwork of women's support centers ranges from one to three years of experience. This indicates that a large number of members have limited experience in the field of women.The proportion of social workers, psychologists and legal specialists working in women's support centers is equal, and this is because the composition of the staff of these centers is based on one specialist from each specialization.

The highest percentage of work was for members of the working group (one - three years) as a result of the recent decision to work in support centers for women. The highest percentage of the staff of the women's support centers have received more than three training courses, indicating that the members of the work team have received training courses qualified to work within the centers to help them to accurate and objective in the use of scientific methods used to manage cases and develop their skills and ability of Scientific knowledge.

Table (3) shows the distribution of respondents (teamwork) According to scientific qualification $n=24$

\begin{tabular}{|c|c|c|c|c|}
\hline No & \multicolumn{2}{|c|}{ Qualitative variables } & Frequency & $\%$ \\
\hline \multirow{3}{*}{1} & \multirow{3}{*}{ Psychologists } & Bachelor of Arts Psychology & 4 & 16.67 \\
\hline & & Master of Psychology & 2 & 8.33 \\
\hline & & PhD in Psychology & 2 & 8.33 \\
\hline \multirow{3}{*}{2} & \multirow{3}{*}{ Social workers } & Bachelor of Social work & 2 & 8.33 \\
\hline & & Master of Social Work & 3 & 12.5 \\
\hline & & Doctor of Social Work & 3 & 12.5 \\
\hline \multirow{2}{*}{3} & \multirow{2}{*}{$\begin{array}{l}\text { Legal } \\
\text { specialists }\end{array}$} & Bachelor of Laws & 3 & 12.5 \\
\hline & & Master of Law & 5 & 20.83 \\
\hline Total & 24 & & \multicolumn{2}{|c|}{ Percentage $100 \%$} \\
\hline
\end{tabular}


As shown in the above table: The highest percentage of psychologists, social and legal specialists working in women's support centers obtained both masters and doctorate degrees. This indicates that scientific expertise helps in the good practice of case management methods within women's support centers.

Table (4) shows the characteristics to be met in the team work

\begin{tabular}{|l|l|c|c|c|c|}
\hline \multirow{2}{*}{ No } & \multicolumn{1}{|c|}{$\mathbf{n}=24$} \\
\cline { 3 - 5 } & & \multicolumn{3}{|c|}{ Responses } \\
\cline { 3 - 5 } & Self confidence & Strong & Medium & Weak & \\
\hline 2 & The ability of democratic leadership & 7 & 3 & 3 & 2.62 \\
\hline 3 & Ability to innovate and innovate & 6 & 16 & 1 & 2.25 \\
\hline 4 & $\begin{array}{l}\text { Understand the nature of working with } \\
\text { others }\end{array}$ & 16 & 5 & 3 & 2.12 \\
\hline 5 & Ability to influence and persuade & 13 & 8 & 3 & 2.44 \\
\hline 6 & Contribution to decision-making & 9 & 11 & 4 & 2.20 \\
\hline 7 & Take responsibility & 11 & 11 & 2 & 2.37 \\
\hline 8 & Ability to study and analyze problems & 14 & 7 & 3 & 2.45 \\
\hline 9 & Ability to negotiate & 16 & 4 & 4 & 2.5 \\
\hline 10 & Ability to cooperate with others & 19 & 3 & 2 & 2.70 \\
\hline 11 & $\begin{array}{l}\text { Ability to configure sound communication } \\
\text { channels }\end{array}$ & 17 & 4 & 3 & 2.58 \\
\hline 12 & Mutual respect among team members & 22 & 2 & 0 & 2.9 \\
\hline & Total & 168 & 89 & 31 & 29.70 \\
\hline & The weighted average & 14 & 7.41 & 2.58 & 2.47 \\
\hline & The ratio & $58 \%$ & $30.9 \%$ & $10.7 \%$ & \\
\hline & Relativity & & $82.33 \%$ & & N=24 \\
\hline
\end{tabular}

As shown in the above table: The characteristics of the team members that enable them to perform effectively are strong, with a relative strength of $82.33 \%$. This may be due to the good selection of elements working in women's support centers or perhaps because of the training courses they have acquired.

Table (5) shows the structural foundations available in the team work of women's support centers

$$
\mathrm{n}=\mathbf{2 4}
$$

\begin{tabular}{|l|l|c|c|c|c|}
\hline \multirow{2}{*}{ No } & \multicolumn{1}{|c|}{ Phrases } & \multicolumn{3}{|c|}{ Responses } & \multirow{2}{*}{ Average } \\
\cline { 3 - 4 } & \multicolumn{1}{|c|}{$\begin{array}{c}\text { Yese } \\
\text { times }\end{array}$} & No & \\
\hline 1 & $\begin{array}{l}\text { Recognition of each member of the team for its } \\
\text { function }\end{array}$ & 20 & 3 & 1 & 2.79 \\
\hline 2 & $\begin{array}{l}\text { Respect each member for work and specialization } \\
\text { for others }\end{array}$ & 20 & 3 & 1 & 2.79 \\
\hline 3 & $\begin{array}{l}\text { The awareness of each member of how to benefit } \\
\text { and benefit }\end{array}$ & 18 & 4 & 2 & 2.67 \\
\hline 4 & $\begin{array}{l}\text { Give each member the opportunity to express his } \\
\text { or her opinion, }\end{array}$ & 17 & 4 & 3 & 2.58 \\
\hline 5 & $\begin{array}{l}\text { The availability of a positive work environment } \\
\text { Procedures and methods of work are clear and } \\
\text { specific }\end{array}$ & 21 & 3 & 0 & 2.87 \\
\hline
\end{tabular}




\section{Egyptian Journal of Social Work (EJSW) http://ejsw.journals.ekb.eg \\ Print ISSN: 2356-9204 Online ISSN: 2356-9212 Vol 9, Issue 1, January 2020}

\begin{tabular}{|l|l|c|c|c|c|}
\hline \multirow{2}{*}{ No } & \multicolumn{1}{|c|}{ Phrases } & \multicolumn{3}{c|}{ Responses } & \multirow{2}{*}{ Average } \\
\cline { 3 - 5 } & \multicolumn{1}{|c|}{ Yes } & $\begin{array}{c}\text { some } \\
\text { times }\end{array}$ & No & \\
\hline 7 & $\begin{array}{l}\text { Having clear time schedules to implement the } \\
\text { work }\end{array}$ & 5 & 7 & 12 & 1.7 \\
\hline 8 & $\begin{array}{l}\text { Availability of degree of freedom in dealing with } \\
\text { situations }\end{array}$ & 10 & 12 & 2 & 2.33 \\
\hline 9 & $\begin{array}{l}\text { There is a clear mechanism for resolving disputes } \\
\text { between members }\end{array}$ & 9 & 12 & 3 & 2.25 \\
\hline 10 & $\begin{array}{l}\text { Expect responsible behavior from all team } \\
\text { members }\end{array}$ & 13 & 6 & 5 & 2.33 \\
\hline & Total & 155 & 56 & 29 & 25.25 \\
\hline & The weighted average & 15.5 & 5.6 & 2.9 & 2.5 \\
\hline & The ratio & 64.5 & 23.3 & 12.0 & $100 \%$ \\
\hline & Relativity & \multicolumn{3}{|c|}{$83.33 \%$} & $\mathrm{~N}=24$ \\
\hline
\end{tabular}

As shown in the above table: The structural foundations available within the team work has a relative strength of $83.33 \%$, and it indicates that the team members in the women's support centers are fully aware of the basics of teamwork and that helps to perform well when dealing with the problems and pressures of life experienced by battered women.

Table (6) shows the indicators of the effective performance of the team $n=24$

\begin{tabular}{|l|l|c|c|c|c|}
\hline \multirow{2}{*}{ No } & \multicolumn{1}{|c|}{ Phrases } & \multicolumn{3}{c|}{ Responses } & \multirow{2}{*}{ average } \\
\cline { 3 - 4 } & & Yes & $\begin{array}{c}\text { some } \\
\text { times }\end{array}$ & No & \\
\hline 1 & Team members feel the importance of goals & 23 & 1 & 0 & 2.95 \\
\hline 2 & $\begin{array}{l}\text { Team members are aware of the nature of their } \\
\text { work }\end{array}$ & 22 & 2 & 0 & 2.91 \\
\hline 3 & $\begin{array}{l}\text { Invest the difference of opinion among team } \\
\text { members }\end{array}$ & 10 & 13 & 1 & 2.37 \\
\hline 4 & Good relations between team members & 22 & 1 & 1 & 2.87 \\
\hline 5 & Performance of roles in a balanced manner & 24 & 0 & 0 & 3 \\
\hline 6 & Recognition of errors regardless of function & 12 & 10 & 2 & 2.41 \\
\hline 7 & $\begin{array}{l}\text { Take advantage of both successful and } \\
\text { unsuccessful experiences }\end{array}$ & 9 & 13 & 2 & 2.29 \\
\hline 8 & perception of time as synonymous with money & 1 & 1 & 22 & 1.12 \\
\hline 9 & Planning to solve problems & 10 & 12 & 2 & 2.33 \\
\hline 10 & Speed in implementing decisions taken & 9 & 13 & 2 & 2.29 \\
\hline 11 & Flexibility in problem solving & 18 & 4 & 2 & 2.67 \\
\hline 12 & Follow-up and continuous evaluation & 13 & 7 & 4 & 2.37 \\
\hline & Total & 173 & 77 & 38 & 29.62 \\
\hline & weighted average & 14.41 & 6.41 & 3.16 & 2.46 \\
\hline & The ratio & 60.0 & 26.7 & 13.1 & $100 \%$ \\
\hline & Relativity & $82.72 \%$ & & $\mathrm{~N}=24$ \\
\hline
\end{tabular}


As shown in the above table: The indicators of effective performance of the team are those that help its members to perform well when dealing with the problems and pressures faced by battered women with a relative strength of $82.27 \%$.

The following table (7) shows: The positions that require cooperation with the working group of women's support centers with a relative strength of $85.67 \%$.

Table (7) shows the positions that require cooperation with the team $n=24$

\begin{tabular}{|l|l|l|l|l|l|}
\hline \multirow{2}{*}{ No } & \multirow{2}{*}{ Phrases } & \multicolumn{3}{c|}{ Responses } & \multirow{2}{*}{ average } \\
\cline { 3 - 6 } & & \multicolumn{2}{|c|}{ Yes $\begin{array}{c}\text { some } \\
\text { times }\end{array}$} & \multirow{2}{*}{ No } & \\
\hline 1 & When you start working with the victim & 7 & 15 & 2 & 2.2 \\
\hline 2 & When writing reports & 19 & 3 & 2 & 2.7 \\
\hline 3 & $\begin{array}{l}\text { In the event of a safety and insurance plan } \\
\text { for the situation }\end{array}$ & 22 & 2 & 0 & 2.9 \\
\hline 4 & $\begin{array}{l}\text { In case the case is referred to competent } \\
\text { authorities }\end{array}$ & 10 & 13 & 1 & 2.3 \\
\hline & Total & 58 & 33 & 5 & 10.28 \\
\hline & The weighted average & 14.5 & 8.25 & 0.71 & 2.57 \\
\hline & The ratio & 60.4 & 34.3 & 5.2 & $100 \%$ \\
\hline & Relativity & $85.67 \%$ & & $\mathrm{~N}=24$ \\
\hline
\end{tabular}

\section{Discussion}

This study attempted to achieve the objective of defining the planning indicators that help develop the role of the work team in the centers to support women in dealing with abused women, by answering the study questions. The results of the study declared that:-

1) The most important features that must be available to the team members, that enable them to perform the work effectively is mutual respect between them, the cooperation between the members of the team is the basis of dealing with each other. This is consistent with the study of (Salem, 2005), (Badawi, 1996), and (Sandra, 1991).

2) The procedures and methods of work are clear, specific. The availability of a positive work environment from the constructive foundations of the team helps them to perform well when dealing with the problems and life pressures faced by abused women. The social worker writes a comprehensive report on the situation that has a clear role in helping the psychologist and legal specialist in identifying the basic factors of the problem and trying to address it. This can only be achieved through a relationship based on trust between the social worker and the rest of the team. This is consistent with the findings of a study on (Dandrawi, 2003), (Shehata, 2004). 
3) The results of the study confirmed the need for cooperation between the social, psychological and legal specialist in favor of abused women. This comes through attention to the theoretical and practical preparation of the team members to play their role in the framework of the teamwork, and the need for each member of the team to clearly understand its function and specialization. This is consistent with the study of (Al-Jaafrawi, 2003), (Salem, 2004) and (Shoman, 2005).

The study produced proposed planning indicators for the development of the role of the teamwork in the use of social support with battered women:

The axes around which planning indicators are based:

\section{The first axis: professional development}

(A) Attention to the selection of elements working in women's support centers and the need to have some inherited and other features that can be acquired through professional development that increases the effectiveness of teamwork,

A-1self-confidence as each member's confidence in himself gives him the ability to deal with the problems presented to him effectively within the members of the team.

A.2 The ability to cooperate with others because the spirit of teamwork leads to fruitful cooperation that is the basis for reaching the support of socially abused women.

A.3 The ability to influence and persuade women who are subject to possible solutions to the problem.

A.4 Understanding the nature of working with others because of the cooperation between the team members, each will understand the nature of his work with others with the team members.

A.5The ability to study and diagnose the problems of well-off women and provide an integrated picture of the social reality of these problems.

B) Conducting continuous training courses that highlight the skills of the staff members of the women's support centers in dealing with the problems faced by battered women and the use of modern methods of training.

\section{The second axis: the structural foundations of the work team}

1 - Respect each member for the work and specialization of each of the other members.

2- Provide each member with the opportunity to express his / her opinion and clarify his role in each individual case. 
3 - The awareness of each member of how to benefit and benefit from other members.

4- Each member of the team is aware of his / her function and is clearly aware of it.

5- Availability of a degree of freedom in dealing with the different positions of the members of the team.

6 - Predicting the responsible behavior of all members of the team as partners in the institutional work.

7- Establish clear timetables for the implementation of the work.

8- Procedures and methods of work should be clear and specific.

9- Establish a clear mechanism for resolving disputes and disputes among the members of the team.

\section{Axis III: Effective Performance Indicators for the Work team}

1. The good relations between the members of the team prevail.

2. The members of the team should have a sense of the importance of the objectives they are working to achieve within the centers, and that their main goal is to preserve the dignity and the dignity of women.

3. Trying to benefit from previous experiences in working well whether successful or impossible to invest or avoid during work.

4. The roles of the team members should be balanced. Each member's knowledge of his / her role and the role of the other members will help the success of the support process.

5. The members of the team try to invest the difference of opinion in order to reach the best proposals and solutions.

6. The problems faced by women must be addressed based on a sound plan developed by the team members based on the causes, factors and outcomes of the problem.

7. The members of the team should present their reports and proposals in the face of the problem presented as soon as possible to have a degree of speed of adjudication.

8. Trying to follow-up and continuous evaluation of the work.

\section{Axis 4: Activities related to the actual roles of the social worker in women's support centers}

1. Receiving the case and making sure that the criteria are met to accept the situation inside the center.

2. Emphasis on the principle of confidentiality.

3. Completion of the data on the reception form.

4. Identify the nature of the problem and try to determine the type of violence to which the situation is exposed. 
5. Identify the social environment surrounding the situation.

6. Determine the type of assistance you wish.

7. Study the problem in all its different aspects and social dimensions.

8. Diagnose the case and determine its causes with all accuracy and objectivity.

9. The spirit of reassurance and containment psychologically and morally.

10. Emphasize that it is an individual situation in society.

11. Trying to determine the type of intervention by transferring it to a psychiatrist or to be satisfied with the advice that you get inside the center.

12. To clarify the nature of the violence and the characterization of the crime and to identify the circumstances of the incident.

13. Clarification of the rights and duties of the case.

14. Clarify the positive and negative effects of recourse to justice.

15. Contribute to the implementation of programs agreed upon in a cooperative framework.

16. Provide advice to other specialties to become more efficient in providing services that fall within their competence and need of battered women.

17. Provide all information that appoints the team to make the appropriate decision with the case.

18. Registration of the professional tasks carried out by the members of the team to take advantage of them when needed.

19. Write a comprehensive report on the situation.

20. Transferring the case to the competent authorities that can benefit from it in the face of its problems.

Axis 5: Difficulties that limit the effectiveness and integrity of the team's roles

1 - The prevalence of mistrust among members confidence is the basis of dealing between members and lost confidence, this negatively affects the construction of the team and thus on the nature of work centers and address the problems experienced by battered women.

2 - The effectiveness of meetings and interviews because meetings and interviews are not conducted regularly among the members of the team and that each member wants to present his idea and opinion without attention to the views of others.

3 - Lack of open communication channels between the members of the team and between them and the outside community. 
4. Lack of effective participation of members of the teamwork in decision-making.

5 - Unwillingness of the team members to play their roles well because of the imposition of control by the authorities and decision makers.

6 - The closure of each specialist on his specialty and not try to benefit from other disciplines.

Axis 6: Proposals to overcome difficulties that limit the effectiveness and complementarity of the roles of the team work

1. The need for cooperation between social, psychological and legal specialists in favor of abused women.

2. Each member of the team must be aware of his / her job and specialization clearly.

3. To agree among the members of the team on the objectives of the team work in support centers for women and to understand these objectives.

4. Achieving positive interaction between the roles of each member of the team in the framework of its function and specialization.

5. Provide open channels of communication between the members of the team to ensure coordination of work between them and prevent recurrence.

6. Encouraging the members of the team to develop professional self in the framework of the teamwork.

8. Organization of training courses to increase the understanding of the members of the teamwork on the dynamics of the teamwork in support centers for battered women.

Finally, there are some indicators for women and their supporters that can confront and prevent any form of violence against women through, inter alia, the following:

1. To raise awareness in the society about the importance of women in society and the fact that they constitute half of society and no form of violence may be exercised against it as a human being with the same rights and duties of men.

2. Raising women's awareness of their rights and values, and teaching them how to be educated, educated, and intellectually independent.

3. Work special projects for women that help them to earn their living without the need of men, especially in the cases of divorced or widowed women so as not to be subjected to various social and family pressures. 
4. Rejecting any form of violence against women, and combating it by addressing violence by any means.

5. Educational information programs will help to spread the sound culture of women.

6. Punishing violators by the government, and protecting women from violence by relatives and society.

\section{Study Limitation:}

1. The process of finding participants to fill out the research questionnaire is a great challenge for the researcher. He should attract individuals based on their suitability to the research criteria, and then ask them what they think and try to convince them to fill out the questionnaire.

2. To persuade institutions to participate in the study, which may be an obstacle and an additional challenge to the researcher to complete his research, especially if the research is classified in the controversial research, or dealing with sensitive issues.

3. Lack of motivation and encouragement, and lack of sense of the researcher excellence and appreciation.

4. Involvement of leaders and administrators unjustified by scientific research, lack of assistance to the researcher.

5. The weak skills and level of expertise of service providers in institutions working with battered women.

\section{REFERENCES}

Abu El-Nasr. M. M., (2004): "team Work in the Field of Care and Rehabilitation of People with Special Needs, Cairo, Arab Nile Group, $1^{\text {st }}$ Ed.

Abu El-Nasr. M. M., (2009): "Successful Work Teams - Building, Growth and Management", (Cairo, Arab Group for Training and Publishing).

Ahmed. M. W., (2015):"A study on the economic cost survey of gender-based violence in Egypt", Central Agency for Public Mobilization and Statistics, Cairo.

Ali. A. M., (2002): "Introduction to social service with models of teaching and practicing the profession in the Arab countries", (Cairo, the library of the Egyptian Renaissance, $1^{\text {st }}$ Ed,).

Al-Jaafrawi. M. I. A., (2003): "Towards a Training Program to Increase the Professional Performance of Social Workers in Personal Status Courts", Unpublished Master Thesis, (Cairo University, Fayoum Branch, and Faculty of Social Work).

Allen, G.R. (1975): The Graduate Students' Guide to Theses and Dissertations, a Practical Manual for Writing and Research. Jossey-Bass Publishers

Badawi. F.H., (1996): "Evaluation of the efficiency and effectiveness of family guidance and counseling offices", Master Thesis, (Cairo University, Fayoum Branch, Faculty of Social Work).

Badawi. Z. A., (1986): "Dictionary of Social Sciences", (Beirut, Lebanon Library). 
Caplan. G., (1981): "Mastery of Stress-Psychological Aspects", American Journal of Psychiatry, vol138.

Dandrawi. A. A., (2003): "The Role of Social Work in the Issues of Khul '", published paper, $16^{\text {th }}$ Scientific Conference (Cairo, Helwan University, Faculty of Social Work, 19-20 March, vol. II).

Deborah. H. M., (1994): "The Team Building", (New York: Amacom).

El Gohary. M. M. \&Abd El -Mohsen. A. A., (1991): "team Work in the Practice of Social Work", published research, $4^{\text {th }}$ Scientific Conference, (Cairo University, Fayoum Branch, Faculty of Social Work, 23-25 April).

Ellsberg M, \& Heise L, (2005): Researching Violence against Women: A Practical Guide for Researchers and Activists. Washington DC, United States: World Health Organization, PATH.

Kassem. M. R., (2004): "Social Work and Human Rights", Working Paper, $17^{\text {th }}$ Scientific Conference, Cairo, Helwan University, Faculty of Social Work.

Mustafa. M. N., (2005): "The role of social worker as a general practitioner with members of the mental health care team", unpublished master thesis (Cairo, Helwan University, Faculty of Social Work,).

Neil. T., (2000): "understanding Social work preparing for Practice", (London: Macmillan press. LTD).

Newspaper Middle East Source http://i.cdn.turner.com.

Niazi. B. A., (2000): "Concepts and Terminology in Social Work", (Riyadh, Obeikan Library, $1^{\text {st }}$ Ed).

Our Watch, (2015): Australia's National Research Organization for Women's Safety (ANROWS) and VicHealth... Change the story: A shared framework for the primary prevention of violence against women and their children in Australia. Melbourne, Australia: Our Watch, 38.

Salem M.I., (2004): "The contents of the qualifying program for the preparation of social workers to work with family disputes in family courts", published research, $15^{\text {th }}$ scientific conference, (Cairo University, Fayoum Branch, Faculty of Social Work,).

Salem. M. I., (2005): "The Judicial System and Social Work", published paper, $18^{\text {th }}$ Scientific Conference, Cairo, Helwan University, Faculty of Social Work, 16-17 March, vol 1.

Sandra. D.,(1991): "Job stress and job satisfaction An analysis of contributing factors for counselors in A court mandated Family conciliation service",( Canada: University of Montaba).

Sayed. M. K., (1993): "Factors Affecting the Practitioner's Social Practice in the Treatment Team", (Unpublished Master Thesis, Cairo University, Fayoum Branch, and Faculty of Social Work).

Selim. M.M., (2006): "Evaluation of the role of social worker with the work team to protect youth groups from addiction", unpublished master thesis, (Cairo, Helwan University, Faculty of Social Work,).

Shehata. M.M. E., (2004): "Evaluation of the Performance of Social Workers in the Personal Status Courts", Journal of Studies in Social Work and Humanities, (Cairo, Helwan University, Faculty of Social Work). 


\begin{tabular}{|llr||}
\hline Egyptian Journal of Social Work (EJSW) & http://ejsw.journals.ekb.eg \\
Print ISSN: 2356-9204 & Online ISSN: 2356-9212 & Vol 9, Issue 1, January 2020 \\
\hline \hline
\end{tabular}

Shoman. A. Y., (2005): "Skills for Social Work Work with Marital Disputes in Family Disputes Settlement Offices", Published Research, 18th Scientific Conference, (Cairo, Helwan University, Faculty of Social Work, 16-17 March, and Vol. I).

Sulaiman. H. H., et al., (2005):"General Practice in Social Work with Community, Institution and Society", (Beirut, Majd University Foundation for Studies, Publishing and Distribution, $\left.1^{\text {st }} \mathrm{Ed}\right)$.

Tomas. R., (2002):"An analysis of the New York county family court workgroup and its impact on the implementation of the New York state family protection and domestic violence intervention Act of 1994", (USA, university of New York).

United Nations, (1993): Declaration on the Elimination of Violence against Women (UN Resolution 48/104 444) Proceedings of the 85th Plenary Meeting. Geneva: United Nations General Assembly.

Webster's New World Dictionary of the American Language, 1964, (United States of America, Vol 2).

WHO, (2016):"Violence against Women: Intimate Partner and Sexual Violence against women", Factsheet No. 239. Geneva. 